\title{
Editor's Introduction: History, Theory and Change
}

\author{
Lawrence T. Nichols ${ }^{1}$
}

Published online: 20 August 2021

(C) The Author(s), under exclusive licence to Springer Science+Business Media, LLC, part of Springer Nature 2021

In this issue we offer a rich set of essays, mostly historical and empirical, along with theoretical reflections on disorder, change and the content of sociological discourse. The articles cover a range of periods, from the 1830s to the recent past, and some provide an international perspective. Three articles, by Efe Peker, by Jyoti Puri, and by Anthony Puddephatt and Oluwatomi Akinyede, were originally submitted in connection with the "new voices in the history of sociology" initiative that became the June 2021 issue, but they were undergoing final revisions when that set had to go to press. They fit very well, however, with the other analyses presented here.

Anja Maria Ariansen raises the issue of the relative lack of participation by sociologists in the recent debate over biosociology that has arisen from important and provocative findings in the biological sciences. Addressing the challenge of how to frame this silence conceptually, Ariansen draws upon two frameworks: Susie Scott's "sociology of nothing," and Christian Smith's model of "sociology's sacred project." The author documents the "silence" through a qualitative analysis of presidential addresses in four sociological associations, as well as the themes of those professional conferences, over the past two decades. Ariansen concludes with a plea for sociologists to engage with the biosociology debate in order to enrich the discipline's understanding and to remain relevant in the larger ongoing discourse. An important implication here is that sociology cannot succeed and prosper as a world unto itself, but that it must remain in touch with peer fields and must retain their respect. This is not to say that sociology should surrender its distinctive perspective - quite the contrary-but that it should avoid isolation and what Sarah Crawley called "encampment" in a 2019 issue of this journal.

Lonnie Athens continues the theoretical project of developing a "radical interactionist" perspective anchored in the idea of domination by revisiting Robert Park's model of social change and seeking to expand it. Athens enlarges Park's approach by increasing the number of phases of change to five, while retaining its conceptual distinction between "community" and "society" as a means of designating starting and end points of the process. The author emphasizes that the proposed approach is not totally deterministic; rather, it recognizes contingencies in the dynamics of

Lawrence T. Nichols

ltnichols@retiree.wvu.edu

1 West Virginia University, Morgantown, WV, USA 
both reformist and revolutionary change. Among the benefits of the model, Athens argues, is that it moves beyond symbolic interactionism, which has not provided a causal model of change.

Reza Azarian also engages with symbolic interactionism in an effort to overcome limitations of the "analytical" model of Desire-Belief-Opportunity (DBO) that was recently introduced by Peter Hedstrom and Peter Bearman. The author argues in particular that the interactionist idea of "the definition of the situation" will enrich the DBO approach and make it into a better tool for empirical investigations. Whereas desire, belief and opportunity can be considered somewhat deterministic factors that condition and help predict courses of action, the definition of the situation approach takes into consideration the agency and creative power of participants. At the same time, incorporating the symbolic interactionist perspective will allow sociologists employing the enlarged model to carry out more empathetic analyses that provide insight into what particular courses of emerging, developing action mean to those involved.

Black Hawk Hancock and Roberta Garner argue that two of Erving Goffman's less noticed concepts, namely, "havoc" and "containment," provide valuable resources for the sociological analysis of current threats to social order as well as the management of these threats. The authors are especially interested in applying Goffman's ideas to the present Covid-19 pandemic and to political unrest (e.g., the January 6, 2021 rempage at the U.S. Capitol), but they see the ideas as also relevant to such issues as cyber hacking and so-called "fake news." In the case of Covid-19, havoc produced by the spread of the virus was somewhat contained via applied medical knowledge, while at the same time it was expanded via campaigns of disinformation, rumors and ideological appeals that created resistance to efforts at prevention. Hancock and Garner seek not merely to apply Goffman's concepts, but also to broaden them by means of what they term a "generative reading." During the review process I commented to the authors that the political polarization of the United States (as in other nations) might also be regarded as a factor producing havoc, especially insofar as it generates and maintains an "enemies" orientation. The field of sociology has resources that would allow it to assume a reconciling, bridgebuilding role that might increase understanding and reduce conflict. But this is not the course of action that has been advocated by the leaders of sociological associations in recent decades, nor is it a message in leading textbooks in the field.

Ivan Kislenko examines recent debates over "global sociology" which, in the author's view, are ultimately about the nature of the discipline itself. Kislenko suggests that the overall debate can be meaningfully divided into two broad phases that extended from about 1982 to 2006, and then from 2006 to the present. In the earlier period, discussion emerged from the observation, which the author credits to Wilbert Moore, that sociology was focused too exclusively on nation-states (a point of view, we might note, that had earlier been argued by one of Moore's teachers, Pitirim Sorokin). This led to much criticism of alleged western-centric and Eurocentric biases in the field. The more recent period can be usefully understood, the author contends, by considering the dispute between Michael Burawoy and Pyotr Sztompka, who have been leading voices in the International Sociological Association. Sztompka has argued for a universalistic and unified model of sociology, 
similar to that of the natural sciences, while Burawoy has advocated localism and indigenous development, though continuing to ground this view in a commitment to what might be considered thoroughly European and western ideals, namely, equality and democratic socialism. Others, such as Raewynn Connell, have independently taken a stance similar to that of Burawoy, and this seems to have become dominant in organizations such as the ISA, where an advocacy of "southern," as opposed to "northern" sociologies has emerged. There is thus the sort of tension that Talcott Parsons earlier analyzed in terms of "universalism versus particularism," which might be considered epistemological, along with political and ethical tension arising from the emergence of what might be broadly termed "liberation sociology."

Efe Peker examines the importance of the study of religion in the historical development of sociology in Europe and in the United States. The author distinguishes three ways in which research on religion had relevance for the discipline: epistemologically, normatively and empirically. The main epistemological issue was the compatibility, or lack of compatibility, between religion and science. The normative question was whether religion should or should not be supported as part of a good or ideal social order. The empirical focus was on the manner in which religion operated within societies, and the ways in which it was changing. Peker concludes that in the decades ahead sociologists generally—not just specialists in religion-should be aware of religion's influence in a globalizing world. Here it might be noted that while the thesis of increasing secularization accompanying modernization may accurately describe events in Europe, there has elsewhere been a spread or revival of religious traditions. The broadest revival has perhaps been manifested in a number of Islamic nations, while Christian faiths have gained adherents in Africa and made inroads in China despite official repression. In Europe, meanwhile, there has been an increasing Islamic presence. The revival of Confucianism in China, the spread of yoga, and the emergence of a discourse of "spirituality" in a number of fields (e.g., medicine, psychology) are also of interest in this connection.

Anthony Puddephatt and Oluwatomi Akinyede examine the development of sociology in Nigeria with an eye toward global dialogue among sociologists. The authors note that early work in the field was largely shaped by ideas and theories imported from Europe, leading to the problem of the "captive mind." They illustrate this through a historical sketch of efforts to apply such ideas as "modernization" and "dependency" theories to the reality of Nigeria. As an alternative for the future, the authors advocate developing more indigenous variants of the discipline that draw upon both pre-colonial cultural resources and the new realities of a post-colonial order. Without entirely rejecting what was earlier imported, sociologists in Nigeria could thereby develop a more authentic voice and make contributions of "epistemic significance" to a global sociology.

Jyoti Puri addresses the historical development of a sociology of death and dying with an overall concern regarding the effects of structured inequalities on these experiences. The author calls attention to the works of three historical figures that arguably have yet to be integrated into the professional literature in this field, namely, Harriet Martineau, Ida Wells and W. E. B. DuBois. All of these writers carried out empirical research on the social, psychological and cultural aspects of death and dying, Martineau within a wide-ranging account of manners and morals, and 
Wells and DuBois with a particular focus on the experiences of African Americans. Martineau and DuBois were at least partly oriented toward the project of building a new science of sociology, while Wells provided valuable materials for such a project through documentation of the lynching of African-Americans, especially in the South. Puri hopes that the article will contribute to the diversification of the sociology of death and dying, while recognizing that this will require much comparative international research as well.

Sandro Segre examines the treatment of religion in the writings of W. E. B. DuBois. The author characterizes DuBois's overall attitude as ambivalent, partly as a result of DuBois's personal experience of embracing, and subsequently rejecting, Christianity. DuBois condemned the "cold formalism" of much Protestant Christianity but appreciated the role of Black Christian churches as centers of communal life. In DuBois's view, expressive religiosity was a genuine feature of African cultural traditions, and participation in religious rituals in the U.S. allowed for communal expression of the experience of oppression. Thus, Black Christian churches served as a primary source of racial consciousness for African Americans.

This set of articles, rich in ideas and empirical detail, are also rich in implication, for they touch on the central and enduring question of what sociologists aspire to be. The older project of building a new science on a par with other sciences does not excite enthusiasm as perhaps it once did, especially as it competes with the project of building a political movement. But if the discipline becomes a movement, whether to the left (as many would desire) or to the right (as is unlikely), how does it produce knowledge that has credibility and validity for non-members of the movement? Knowledge "for members only" or "for believers only" is not likely to have the sort of impact on the world that advocates might wish, and it is questionable whether sociologists have the right to impose it on non-believing students. Burawoy, a leading voice for "public" sociology (with its partisanship), has also argued that this must be grounded in high-quality "professional" sociology (which is in principle non-partisan). How is this tension to be resolved in the years ahead: via compromise, via the victory of one approach, or via a schism between those who wish to build a science and those who wish to build a movement? Such issues cannot be resolved here, but this journal can perhaps serve as a medium for their exploration.

Publisher's Note Springer Nature remains neutral with regard to jurisdictional claims in published maps and institutional affiliations. 